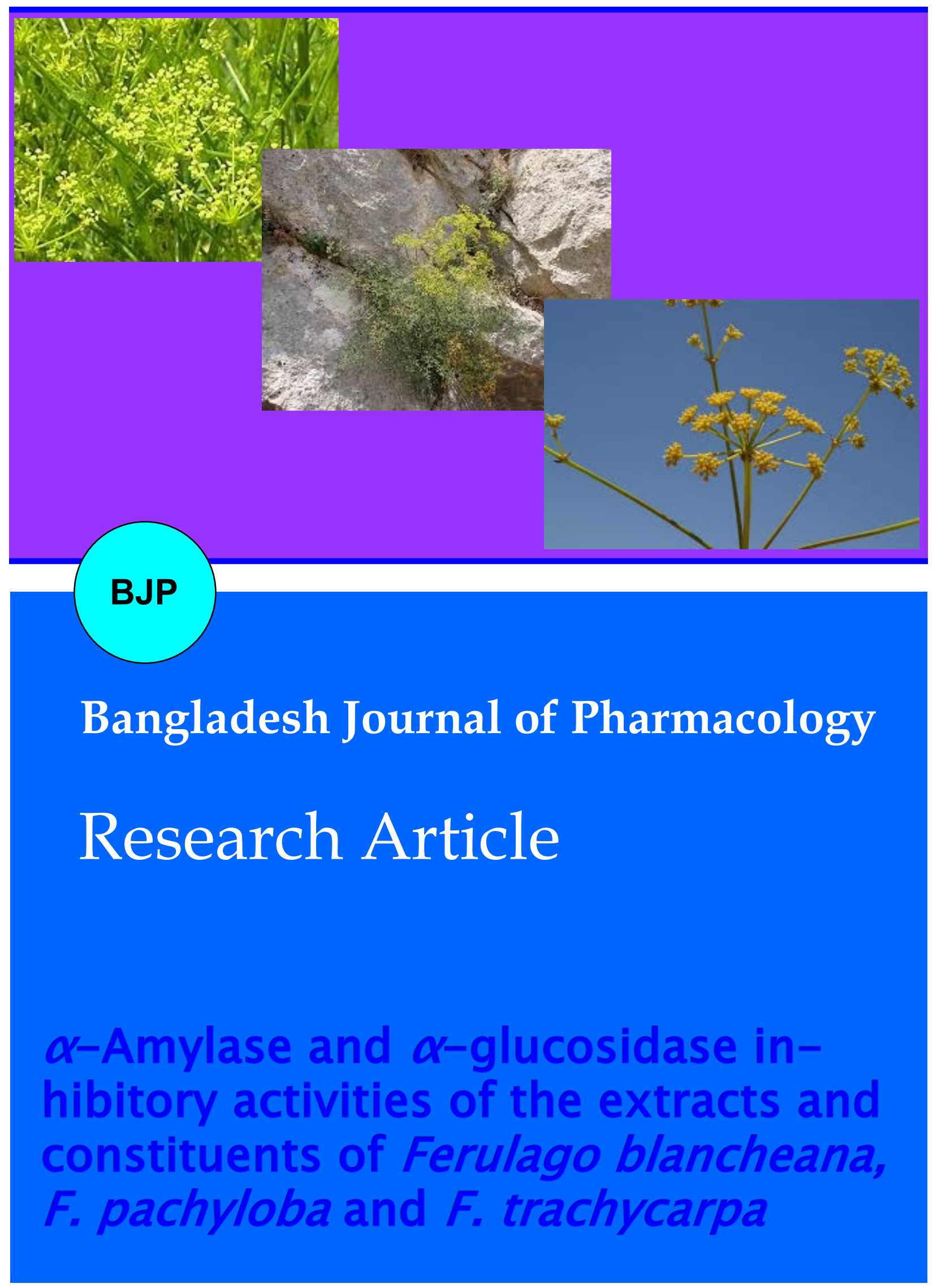




\section{$\alpha$-Amylase and $\alpha$-glucosidase inhibitory activities of the extracts and constituents of Ferulago blancheana, F. pachyloba and $F$. trachycarpa roots}

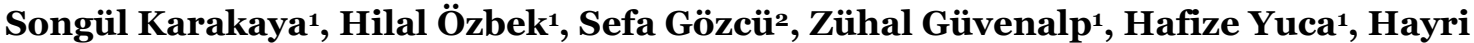 Duman', Cavit Kazaz4 and Ceyda Sibel Kiliç5}

${ }^{1}$ Department of Pharmacognosy, Faculty of Pharmacy, Atatürk University, Erzurum 25240, Turkey; ${ }^{2}$ Department of Pharmacognosy, Faculty of Pharmacy, Erzincan University, Erzincan 24100, Turkey; ${ }^{3}$ Department of Biology, Faculty of Science, Gazi University, Ankara 06500, Turkey; ${ }^{4}$ Department of Chemistry, Faculty of Science, Atatürk University, Erzurum 25240, Turkey; ${ }^{5}$ Department of Pharmaceutical Botany, Faculty of Pharmacy, Ankara University, Ankara 06100, Turkey.

\begin{tabular}{|c|c|}
\hline Article Info & \\
\hline Received: & 23 August 2017 \\
\hline Accepted: & 18 January 2018 \\
\hline Available Online: & 5 February 2018 \\
\hline DOI: $10.3329 /$ bjp.v & $3 i 1.33668$ \\
\hline $\begin{array}{l}\text { Cite this article: } \\
\text { Karakaya S, Özb } \\
\text { Güvenalp Z, Yuca } \\
\text { zaz C, Kiliç CS. } \\
\text { glucosidase inhibit } \\
\text { extracts and const } \\
\text { blancheana, F. pach } \\
\text { carpa roots. Bangla } \\
\text { 2018; 13: 35-40. }\end{array}$ & $\begin{array}{l}\text { k H, Gözcü S, } \\
\text { H, Duman H, Ka- } \\
\text {-Amylase and a- } \\
\text { ry activities of the } \\
\text { uents of Ferulago } \\
\text { oba and F. trachy- } \\
\text { lesh J Pharmacol. }\end{array}$ \\
\hline
\end{tabular}

\begin{abstract}
Eleven coumarins named osthole (1), imperatorin (2), bergapten (3), prantschimgin (4), grandivitinol (5), suberosin (6), xanthotoxin (7), felamidin (8), marmesin (9), umbelliferone (10), ulopterol (11), and a sterol mixture consisted of stigmasterol (12), $\beta$-sitosterol (13) were isolated from the roots of Ferulago blancheana, F. pachyloba and F. trachycarpa through in vitro bioassayguided fractionation processes. The extracts and bioactive compounds were evaluated for their a-amylase and a-glucosidase activities. Among the tested compounds, felamidin and suberosin showed significant a-glucosidase inhibitory activity with $\mathrm{IC}_{50}$ values of 0.4 and $0.9 \mathrm{mg} / \mathrm{mL}$, respectively, when compared to the reference standard acarbose $\left(\mathrm{IC}_{50}=4.9 \mathrm{mg} / \mathrm{mL}\right)$. Grandivitinol $\left(\mathrm{IC}_{50}=20.0 \mathrm{mg} / \mathrm{mL}\right.$ ) had the lowest inhibitory effect. On the other hand, none of the tested extracts were found to be active on $a$-amylase inhibition. This is the first report on isolation, characterization of the bioactive compounds and evaluation the $a$-amylase and $a$-glucosidase inhibitory activities of these species.
\end{abstract}

\section{Introduction}

Ferulago W. Koch. is a perennial genus of Apiaceae and is represented by approximately 50 taxa throughout the world and 35 taxa (18 of them are endemics) in Turkey. Hence Anatolia is considered as the gene center of this genus (Güner et al., 2012). F. blancheana Post ex Boiss. and F. pachyloba (Fenzl) Boiss. are endemic perennial species, growing only in Niğde-Central Anatolia and Kayseri-Central Anatolia, Turkey respectively, however F. trachycarpa Boiss. is not an endemic species, growing in Antalya-Southeastern Anatolia, Turkey (Peşmen, 1972; Troia et al., 2012)
Ferulago species have been used in folk medicine as digestive, carminative, tonic, sedative, vermifuge and aphrodisiac. It is also used to relieve headache, ulcers, hemorrhoids, snake bites, and spleen diseases. Ferulago species are used as salad or spice and food for goats and deers (Erdurak, 2003).

Coumarins, indicated as the common metabolites of Ferulago species (Erdurak, 2003), have various biological activities such as antihyperglycemic (Tchamadeu et al., 2010), antidiabetic (Patel et al., 2012), anti-hypertensive (Gantimur et al., 1986), antiadipogenic (Shin et al., 2010), anticoagulant, anti-inflammatory, antibacterial, 
antifungal, antiviral (Venugopala et al., 2013), antitubercular (Chiang et al., 2010), anti-cancer (Luo et al., 2011), anti-oxidant (Basile et el., 2009), anti-convulsant (Luszczki et al., 2009) and neuroprotective (Wang et al., 2012).

Coumarins may be a potential source of new antidiabetic agents and may also be useful for peripheral tissues by improving the insulin resistance and the increasing glucose uptake (Zhang et al., 2017). Peucedanol 7-O- $\beta$-D-glucopyranoside (Lee et al., 2004), coumarin (1,2-benzopyrone) (Pari and Rajarajeswari, 2009), umbelliferone (Ramesh and Pugalendi, 2005), imperatorin, psoralen, 5-methoxypsoralen, 8-methoxypsoralen, iso-oxypeucedanin, pabulenol, oxypeucedanin methanolate, oxypeucedanin hydrate (Shalaby et al., 2014), iso-bergapten, pimpinellin, isopimpinellin, sphondin, scopoletin, phellopterin, byakangelicin and daucosterol (Zhang et al., 2017) were isolated from various plants belonging to the Apiaceae family and they were found to be antidiabetic. So, it may be a good approach in the treatment of type 2 diabetes.

This is the first report of the isolation and structure elucidation study on the roots of $F$. blancheana, $F$. pachyloba and F. trachycarpa to afford 11 coumarins (111) and a sterol mixture (12-13). The a-amylase and $a$ glucosidase inhibitory activities of the isolated coumarins were also evaluated.

\section{Materials and Methods}

\section{General experimental procedures}

NMR spectra were recorded on a Varian Mercury Plus at $400 \mathrm{MHz}$ for ${ }^{1} \mathrm{H}$ NMR and $100 \mathrm{MHz}$ for ${ }^{13} \mathrm{C} \mathrm{NMR}$ by using TMS as the internal standard. The solvents were $\mathrm{CDCl}_{3}$. ESI-MS was performed on Waters Micromass ZQ mass spectrometer. Column chromatographies were performed on silica gel 60 (0.063-0.200 mm, Merck) and sephadex LH-20 (Fluka). Thin layer chromatography (TLC) was carried out on pre-coated Kieselgel $60 \mathrm{~F}_{254}$ aluminum sheets (Merck).

\section{Plant material}

Flowering plants of F. blancheana, F. pachyloba and F. trachycarpa were collected in 2014 from the Antalya, Niğde and Kayseri (Turkey), respectively and identified by one of the authors (Hayri Duman). The voucher specimens were kept in the Herbarium of Ankara University, Faculty of Pharmacy (Herbarium numbers: AEF 26677, AEF 26674 and AEF26673, respectively).

\section{Extraction and isolation}

Air-dried roots of F. blancheana (750 g), F. pachyloba (600 g) and $F$. trachycarpa $(450 \mathrm{~g})$ were powdered and macerated three times with methanol for 8 hours in a water bath not exceeding $45^{\circ} \mathrm{C}(4 \times 2 \mathrm{~L})$ using a mechanical mixer at $300 \mathrm{rpm}$. The combined extracts were filtered and concentrated till dryness, then dispersed in methanol-water (1:9) and fractionated four times with $400 \mathrm{~mL}$ of dichloromethane, ethyl acetate and $n$-butanol, respectively. The same extraction and fractionation procedure were applied for the aerial parts of the plants. On the other hand, $50 \mathrm{~g}$ of roots and aerial parts were grounded and macerated with $500 \mathrm{~mL}$ of distilled water for 8 hours $/ 3$ days at 30 to $35^{\circ} \mathrm{C}$. The amounts of the powdered plants and obtained extracts are shown in Table I.

As a result of the bioguided fractionation study, the effective dichloromethane extracts of the roots of all species were first submitted to a silica gel column and eluted with a gradient of $n$-hexane:ethyl acetate (100:0 $\rightarrow$ 0:100, v/v) and ethyl acetate:methanol (100:0 $\rightarrow$ $0: 100, v / v)$, and nine fractions (Fr. A-I) were obtained. Fr. A was subjected to a silica gel column which was eluted with a mixture of $n$-hexane:ethyl acetate (95:5) and compounds $\mathbf{1 2}$ and $\mathbf{1 3}$ were obtained as a mixture (217 mg). Repetitive silica gel column chromatography with n-hexane-ethyl acetate (90:10 and 95:5) solvent system on Fr. B gave the compound 1 (220 mg). Fr. C was applied to the silica gel column eluting with $n$ hexane:ethyl acetate (85:15) and sephadex LH-20 column eluting with ethyl acetate to give the compounds 2 (125 mg) and compound 3 (130 mg). Eluting with $n$-hexane-ethyl acetate (90:10) over silica gel column of Fr. D gave the compound $4(400 \mathrm{mg})$ and Fr. E gave the compounds 5 (150 mg) and compound 6 (330 $\mathrm{mg})$. Fr. F eluted with $25 \%$ ethyl acetate in $n$-hexane and rechromatographed with $25 \%$ ethyl acetate in $n$-hexane on the silica gel column to obtain compound 7 (110 mg).

\section{Table I}

Amounts of the powdered plants and obtained extracts

\begin{tabular}{|c|c|c|c|c|c|c|c|c|}
\hline Species & Used parts & $\begin{array}{c}\text { Powdered } \\
\text { (g) }\end{array}$ & $\begin{array}{c}\mathrm{MeOH} \\
(\mathrm{g})\end{array}$ & $\begin{array}{c}\mathrm{CH}_{2} \mathrm{Cl}_{2} \\
\text { (g) }\end{array}$ & $\begin{array}{c}\text { EtOAc } \\
(\mathrm{g})\end{array}$ & $\begin{array}{c}\mathrm{BuOH} \\
(\mathrm{g})\end{array}$ & $\begin{array}{l}\text { Aqueous residue } \\
\text { (g) }\end{array}$ & $\begin{array}{l}\text { Lyophilized } \\
\text { (g) }\end{array}$ \\
\hline \multirow[t]{2}{*}{ F. blancheana } & Root & 750 & 86.6 & 28.5 & 2.3 & 12.2 & 23.4 & 5.8 \\
\hline & Aerial part & 50 & 3.2 & 1.9 & 0.5 & 0.6 & 0.4 & 1.8 \\
\hline \multirow[t]{2}{*}{ F. pachyloba } & Root & 600 & 83.3 & 23.6 & 1.5 & 13.1 & 21.3 & 5.0 \\
\hline & Aerial part & 50 & 3.3 & 1.8 & 0.5 & 0.6 & 0.5 & 2.0 \\
\hline \multirow[t]{2}{*}{ F. trachycarpa } & Root & 450 & 86.8 & 26.3 & 2.4 & 13.5 & 22.1 & 4.8 \\
\hline & Aerial part & 50 & 3.4 & 1.7 & 0.5 & 0.6 & 0.6 & 1.7 \\
\hline
\end{tabular}


<smiles>COc1ccc2ccc(=O)oc2c1CC=C(C)C</smiles>

1<smiles>CC(C)=CCOc1c2occc2cc2ccc(=O)oc12</smiles>

2<smiles>COc1c2ccoc2cc2oc(=O)ccc12</smiles>

3

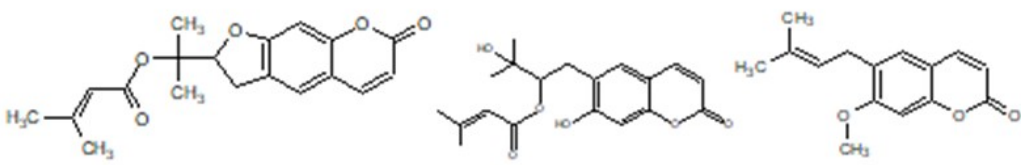

4

5

6<smiles>COc1c2occc2cc2ccc(=O)oc12</smiles>

7<smiles>O=c1ccc2ccc(O)cc2o1</smiles>

10

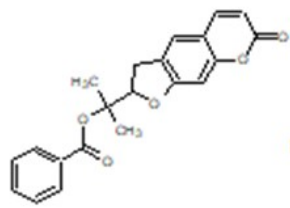

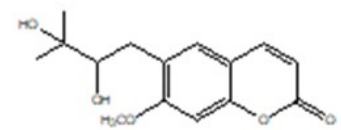

11<smiles>CC(C)(O)C1Cc2cc3ccc(=O)oc3cc2O1</smiles>

9

Figure 1: Chemical structures of compounds 1-13

Fr. G was fractioned by column chromatography over silica gel using $n$-hexane:ethyl acetate mixtures (70:30 and 90:10) consecutively and compound 8 was obtained (325 mg). Fr. H was submitted on a silica gel column using $n$-hexane:ethyl acetate (65:35) to yield compound 9 and the resulting fraction was chromatographed on the silica gel column using $n$-hexane:ethyl acetate $(90: 10)$ to give the compound 10. Fr. I gave the compound 11 (320 mg). Compounds 1-4, 5, 7, 8, 10 and 12-13 were isolated by the same chromatographic methods in all species. Compounds 6 and 11 were isolated only from the dichloromethane fraction of the roots from F. trachycarpa. Compound 9 was isolated only from the dichloromethane fraction of the roots from F. blancheana (Figure 1).

\section{a-Amylase inhibitory activity}

a-Amylase inhibitory activity was established in accordance with the reported method (Nampoothiri et al., 2011) with slight modifications. $1 \%$ Starch solution (100 $\mu \mathrm{L}$ ) in $20 \mathrm{mM}$ sodium phosphate buffer ( $\mathrm{pH} 6.9$ with $6 \mathrm{mM}$ sodium chloride) and sample solutions $(100 \mu \mathrm{L})$ were incubated at $25^{\circ} \mathrm{C}$ for $10 \mathrm{~min}$ in 24-well microplate. Afterwards incubation, $100 \mu \mathrm{L} a$-amylase solution $(0.5 \mathrm{mg} / \mathrm{mL})$ was added to each well and the reaction mixtures were incubated at $25^{\circ} \mathrm{C}$ for $10 \mathrm{~min}$. In order to stop the reaction after the incubation, dinitrosalicylic acid color reagent $(200 \mu \mathrm{L})$ was added and then the microplate was incubated in a boiling water bath for $5 \mathrm{~min}$ and cooled at room temperature. It was taken 50 $\mu \mathrm{L}$ from each well and then was added to 96-well microplate. The reaction mixture was diluted by adding $200 \mu \mathrm{L}$ distilled water and the absorbance was measured at $540 \mathrm{~nm}$. Each assay for all samples was carried out in triplicate. Percentage inhibitions of all samples were calculated using the equation at following:

$\%$ Inhibition $=\left(1-\frac{\triangle \mathrm{A}_{\text {sample }}}{\triangle \mathrm{A}_{\text {control }}}\right) \times 100$

\section{a-Glucosidase inhibitory activity}

a-Glucosidase inhibitory activity was established by using a 96-well microtiter plate in accordance with the described method (Tao et al., 2013) with slight modifications. $p$-Nitro-phenyl- $a$-D-glucopyranoside ( $p$-NPG) was used as the substrate and was prepared in $0.1 \mathrm{M}$ potassium phosphate buffer ( $\mathrm{pH}$ 6.8). a-Glucosidase (0.1 unit/mL, enzyme solution) was dissolved in the same buffer. The samples were dissolved in dimethyl sulfo- 
xide (DMSO) and all samples $(20 \mu \mathrm{L})$ together with the enzyme solution $(20 \mu \mathrm{L})$ were mixed in the plate. Afterward, the substrate $(40 \mu \mathrm{L})$ was added for initiation of the reaction and the mixture was incubated at $37^{\circ} \mathrm{C}$ for $40 \mathrm{~min}$. After incubation, $0.2 \mathrm{M}$ sodium carbonate $(80 \mu \mathrm{L})$ in phosphate buffer ( $\mathrm{pH}$ 6.8) was added to all wells in order to quench the reaction. The amount of released $p$-nitrophenol ( $\mathrm{pNP}$ ) was measured at $405 \mathrm{~nm}$ using a 96-well microplate reader. Each assay for all samples was carried out in triplicate. Percentage inhibitions of all samples were calculated using the equation at following:

\%Inhibition $=\left(1-\frac{\triangle \mathrm{A}_{\text {sample }}}{\triangle \mathrm{A}_{\text {control }}}\right) \times 100$

\section{Results and Discussion}

Methanol extracts of the roots of three Ferulago species were fractionated using solvents with different polarities (dichloromethane, ethyl acetate and $n$-butanol) and the obtained fractions were evaluated for their $a$ amylase and a-glucosidase inhibitory activities. The active dichloromethane extracts were subjected to column chromatography over silica gel and sephadex LH-20. As the result, eleven coumarins osthole (1) (Sajjadi et al., 2009), imperatorin (2) (Muller et al., 2004), bergapten (3) (Stevenson et al., 2003), prantschimgin (4) (Sajjadi et al., 2015), grandivitinol (5) (Abyshe et al., 1977), suberosin (6) (Tabanca et al., 2016), xanthotoxin (7) (Stevenson et al., 2003), felamidin (8) (Kilic et al., 2006), marmesin (9) (Abreu et al., 2010), umbelliferone (10) (Singh et al., 2010), ulopterol (11) (Doganca et al., 1979) and a sterol mixture consisted of stigmasterol (12), $\beta$-sitosterol (13) (Woldeyes et al., 2012) (Figure 1) were isolated and identified.

The extracts and compounds 1-11, obtained via bioassay guided fractionation and isolation process, were evaluated for their in vitro a-amylase and $a$-glucosidase inhibitory activities. The $\mathrm{IC}_{50}$ values and inhibitory effects (\%) are given in Table II. Acarbose was used as a reference standard for both assays. Dichloromethane extracts of roots from F. blancheana, F. pachyloba and F. trachycarpa showed significant activities against aglucosidase with $\mathrm{IC}_{50}$ value of $2.0,2.0$ and $0.3 \mathrm{mg} / \mathrm{mL}$, respectively. Among the tested compounds felamidin $\left(\mathrm{IC}_{50} 0.4 \mathrm{mg} / \mathrm{mL}\right)$ possessed the best inhibitory activity which was more potent than acarbose $\left(\mathrm{IC}_{50} 5.0 \mathrm{mg} /\right.$ $\mathrm{mL}$ ). Suberosin, osthole, imperatorin, prantschimgin and marmesin also showed a-glucosidase inhibitory activity ( $\mathrm{IC}_{50} 0.9,1.0,1.2,1.9,3.0 \mathrm{mg} / \mathrm{mL}$, respectively) which had lower effect than felamidin but stronger than acarbose. On the other hand, none of the extracts showed meaningful $a$-amylase inhibitory activity, while acarbose indicated $82.3 \%$ inhibition at a concentration of $1 \mathrm{mg} / \mathrm{mL}$. These results indicate that felamidin was eleven times more effective than acarbose against $a$ - glucosidase. To our knowledge, no previous study have been reported on a-glucosidase and a-amylase inhibitory activities of F. blancheana, F. pachyloba and F. trachycarpa and the isolated coumarins prantschimgin, felamidin, grandivitinol and suberosin. Also this is the first report on phytochemical analysis of these species. Our results are similar to the previous studies performed on related coumarins. Shalaby et al. (2014) found that imperatorin (at $1000 \mu \mathrm{g} / \mathrm{mL}$ a-glucosidase inhibition\% was found to be $69.7 \pm 3.7$ and we found an inhibition of $89.9 \pm 0.9 \%$ at a concentration of $5000 \mu \mathrm{g} /$ $\mathrm{mL}$ ) showed appreciable antidiabetic activity. Comparing these results with previous studies in which $a$ glucosidase $\mathrm{IC}_{50}$ value of umbelliferone was found to be $7.8 \pm 0.1 \mu \mathrm{g} / \mathrm{mL}$, we have found a higher inhibitory activity with $9.3 \mathrm{mg} / \mathrm{mL}$ (Ramith et al., 2014). Comparing these results with another previous study in which a-glucosidase $\mathrm{IC}_{50}$ value of umbelliferone was $0.5 \mathrm{mg} /$ $\mathrm{mL}$ at $0.5 \mathrm{mg} / \mathrm{mL}$, the inhibitory activity that we have found was again higher (Ayyasamy and Rajamanickam, 2015).

\section{Conclusion}

Among the compounds isolated from $\mathrm{CH}_{2} \mathrm{Cl}_{2}$ fractions of F. blancheana, F. pachyloba and F. trachycarpa roots, coumarins were determined the main chemical constituents of these fractions. The most potent compounds were felamidin and suberosin.

\section{Conflict of Interest}

The authors declare that they have no conflict of interest.

\section{Acknowledgement}

This study was supported by the Scientific and Techno-logical Research Council of Turkey (TUBITAK 115S009).

\section{References}

Abreu VGC, Silva MC, Magalhães RM, Piló-Veloso D, Xavier IFS, Oliveira PM, Alcântara AFC. Chemical constituents from the stem of Brosimum potabile (Moraceae). Acta Amazonica. 2010; 40: 711-18.

Abyshe AZ, Denisenko PP, Abyshev DZ, Kerumov YB. Coumarin composition of Seseli grandivittatum. Khim Prir Soedin. 1977; 5: 640-46.

Ayyasamy R, Rajamanickam M. In vitro a-amylase and aglucosidase inhibition activity of umbelliferone and $\beta$-ionone isolated from Coriandrum sativum Linn. World J Pharm Sci 2015; 5: 1280-89.

Basile A, Sorbo S, Spadaro V. Anti-microbial and anti-oxidant activities of coumarins from the roots of Ferulago campestris (Apiaceae). Molecules 2009; 14: 939-52. 


\section{Table II}

a-Glucosidase inhibitory activities of extracts, fractions and compounds from Ferulago blancheana, F. pachyl$o b a$ and F. trachycarpa

\begin{tabular}{|c|c|c|c|c|}
\hline Species & $\begin{array}{l}\text { Extracts/fractions/ } \\
\text { compounds }\end{array}$ & $\begin{array}{c}\text { Concentration } \\
(\mu \mathrm{g} / \mathrm{mL})\end{array}$ & $\begin{array}{l}\text { a-Glucosidase inhibi- } \\
\text { tion (\%) }\end{array}$ & $\begin{array}{l}\text { IC } \mathrm{I}_{50} \text { value } \\
(\mathrm{mg} / \mathrm{mL})\end{array}$ \\
\hline \multirow[t]{7}{*}{ F. blancheana } & Methanol extract & 5000 & $77.3 \pm 0.1$ & 2.2 \\
\hline & Methanol extract & 2000 & $49.2 \pm 0.5$ & 2.2 \\
\hline & Dichloromethane fraction & 5000 & $79.8 \pm 1.0$ & 2.0 \\
\hline & Dichloromethane fraction & 2000 & $50.2 \pm 0.6$ & 2.0 \\
\hline & Ethyl acetate fraction & 5000 & ND & ND \\
\hline & $n$-Butanol fraction & 5000 & ND & ND \\
\hline & Aqueous residue fraction & 5000 & ND & ND \\
\hline \multirow[t]{9}{*}{ F. pachyloba } & Methanol extract & 5000 & $68.2 \pm 0.7$ & 3.2 \\
\hline & Methanol extract & 2000 & $40.7 \pm 0.1$ & 3.2 \\
\hline & Dichloromethane fraction & 5000 & $89.9 \pm 0.5$ & 2.0 \\
\hline & Dichloromethane fraction & 2000 & $52.8 \pm 0.1$ & 2.0 \\
\hline & Ethyl acetate fraction & 5000 & $72.1 \pm 0.2$ & 3.0 \\
\hline & Ethyl acetate fraction & 2000 & $40.1 \pm 0.1$ & 3.0 \\
\hline & $n$-Butanol fraction & 5000 & ND & ND \\
\hline & Aqueous residue fraction & 5000 & ND & ND \\
\hline & Aqueous extract & 5000 & ND & ND \\
\hline \multirow[t]{8}{*}{ F. trachycarpa } & Methanol extract & 5000 & $88.7 \pm 0.7$ & 0.4 \\
\hline & Methanol extract & 2000 & $82.1 \pm 0.2$ & 0.4 \\
\hline & Dichloromethane fraction & 5000 & $89.1 \pm 0.2$ & 0.3 \\
\hline & Dichloromethane fraction & 2000 & $85.3 \pm 0.4$ & 0.3 \\
\hline & Ethyl acetate fraction & 5000 & ND & ND \\
\hline & $n$-Butanol fraction & 5000 & ND & ND \\
\hline & Aqueous residue fraction & 5000 & ND & ND \\
\hline & Aqueous extract & 5000 & ND & ND \\
\hline \multirow[t]{2}{*}{ Osthole } & & 5000 & $93.3 \pm 0.3$ & 1.0 \\
\hline & & 2000 & $84.3 \pm 1.7$ & 1.0 \\
\hline \multirow[t]{2}{*}{ Imperatorin } & & 5000 & $89.0 \pm 0.9$ & 1.2 \\
\hline & & 2000 & $63.1 \pm 0.7$ & 1.2 \\
\hline \multirow[t]{2}{*}{ Bergapten } & & 5000 & $42.3 \pm 0.4$ & 6.1 \\
\hline & & 2000 & $39.7 \pm 2.4$ & 6.1 \\
\hline \multirow[t]{2}{*}{ Prantschimgin } & & 5000 & $68.2 \pm 0.4$ & 1.9 \\
\hline & & 2000 & $52.0 \pm 0.0$ & 1.9 \\
\hline \multirow[t]{2}{*}{ Grandivitinol } & & 5000 & $12.3 \pm 0.4$ & 20.0 \\
\hline & & 2000 & $7.8 \pm 0.7$ & 20.0 \\
\hline \multirow[t]{2}{*}{ Suberosin } & & 5000 & $88.9 \pm 1.1$ & 0.9 \\
\hline & & 2000 & $81.6 \pm 1.2$ & 0.9 \\
\hline \multirow[t]{2}{*}{ Xanthotoxin } & & 5000 & $45.8 \pm 4.8$ & 5.4 \\
\hline & & 2000 & $38.0 \pm 8.6$ & 5.4 \\
\hline \multirow[t]{2}{*}{ Felamidin } & & 5000 & $94.6 \pm 0.1$ & 0.4 \\
\hline & & 2000 & $64.9 \pm 2.1$ & 0.4 \\
\hline \multirow[t]{2}{*}{ Marmesin } & & 5000 & $84.8 \pm 3.2$ & 3.0 \\
\hline & & 2000 & $32.8 \pm 2.2$ & 3.0 \\
\hline \multirow[t]{2}{*}{ Umbelliferone } & & 5000 & $10.3 \pm 0.5$ & 9.3 \\
\hline & & 2000 & $8.8 \pm 0.0$ & 9.3 \\
\hline \multirow[t]{2}{*}{ Ulopterol } & & 5000 & $50.6 \pm 2.8$ & 5.1 \\
\hline & & 2000 & $42.9 \pm 3.1$ & 5.1 \\
\hline \multirow[t]{2}{*}{ Acarbose } & & 5000 & $50.8 \pm 2.5$ & 5.0 \\
\hline & & 2000 & $29.4 \pm 1.7$ & 5.0 \\
\hline
\end{tabular}


Chiang CC, Cheng MJ, Huang HY, Chang HS, Wang CJ, Chen IS. Prenyl coumarins from Fatoua pilosa. J Nat Prod. 2010; 73: 1718-22.

Doganca S, Ulubelen A, Ishikawa T, Ishii H. (+)-Peucedanol methyl ether from Hippomarathrum cristatum, Umbelliferae. Chem Pharm Bull. 1979; 27: 1049-50.

Erdurak CS. In: PhD [Investigations on Ferulago isaurica Peşmen and F. syriaca Boiss. (Umbelliferae) species]. Ankara, Turkey, Ankara University, 2003, pp 1-2.

Gantimur D, Syrchina AI, Semenov AA. Khellactone derivatives from Phlojodicarpus sibiricus. Chem Nat Compd. 1986; 22: 103-04.

Güner A, Aslan S, Ekim T, Vural M, Babaç MT. In: Türkiye Bitkileri Listesi (Damarlı Bitkiler). İstanbul, Turkey, Nezahat Gökyiğit Botanic Garden Publications, 2012, pp 62-64.

Kilic CS, Okada Y, Coskun M, Okuyama T. New furanocoumarins isolated from the roots of Ferulago isaurica Pesmen growing in Turkey. Heterocycles 2006; 69: 481-86.

Lee SO, Choi SZ, Lee JH, Chung SH, Park SH, Kang HC, Yang EY, Cho HJ, Lee KR. Antidiabetic coumarin and cyclitol compounds from Peucedanum japonicum. Arch Pharm Res. 2004; 27: 1207-10.

Luo KW, Sun JG, Chan JY. Anti-cancer effects of imperatorin isolated from Angelica dahurica: Induction of apoptosis in HepG2 cells through both death-receptor and mitochondriamediated pathways. Chemotherapy 2011; 57: 449-59.

Luszczki JJ, Wojda E, Andres-Mach M. Anticonvulsant and acute neurotoxic effects of imperatorin, osthole and valproate in the maximal electroshock seizure and chimney tests in mice: A comparative study. Epilepsy Res. 2009; 85: 293-99.

Muller M, Byres M, Jaspars M, Kumarasamy Y, Middleton M, Nahar L, Mohammad S, Sarker SD. 2D NMR spectroscopic analyses of archangelicin from the seeds of Angelica archangelica. Acta Pharm. 2004; 54: 277-85.

Nampoothiri SV, Prathapan A, Cherian OL, Raghu KG, Venugopalan VV, Sundaresan A. In vitro anti-oxidant and inhibitory potential of Terminalia bellerica and Emblica officinalis fruits against LDL oxidation and key enzymes linked to type 2 diabetes. Food Chem Toxicol. 2011; 49: 125-31.

Pari L, Rajarajeswari N. Efficacy of coumarin on hepatic key enzymes of glucose metabolism in chemical induced type 2 diabetic rats. Chem Biol Interact. 2009; 181: 292-96.

Patel DK, Prasad SK, Kumar R, Hemalatha S. An overview on antidiabetic medicinal plants having insulin mimetic property. Asian Pac J Trop Biomed. 2012; 2: 320-30.

Peşmen H. Ferulago W. Koch. In: Flora of Turkey and the East Aegean Islands. Davis PH (ed). Vol. 4. Edinburgh, Edinburgh University Press, 1972, pp 469-71.

Ramesh B, Pugalendi KV. Antihyperlipidemic and antidiabetic effects of umbelliferone in streptozotocin diabetic rats. Yale J Biol Med. 2005; 78: 189-96.

Ramith R, Prithvi S, Shirahatti FZ, Lakshmi V, Ranganatha MN, Nagendra P. Inhibitory effect of banana (Musa sp. var. nanjangud rasa bale) flower extract and its constituents umbelliferone and lupeol on $a$-glucosidase, aldose reductase and glycation at multiple stages. S Afr J Bot. 2014; 95: 54-63.
Sajjadi SE, Zeinvand H, Shokoohinia Y. Isolation and identifycation of osthol from the fruits and essential oil composition of the leaves of Prangos asperula Boiss. Res Pharm Sci. 2009; 4: 19-23.

Sajjadi SE, Jamali M, Shokoohinia Y, Abdi G, Shahbazi B, Fattahi A. Anti-proliferative evaluation of terpenoids and terpenoid coumarins from Ferulago macrocarpa (Fenzl) Boiss. fruits. Pharmacognosy Res. 2015; 7: 322-28.

Shalaby NMM, Abd-Alla HI, Aly HF, Albalawy MA, Shaker $\mathrm{KH}$, Bouajila J. Preliminary in vitro and in vivo evaluation of anti-diabetic activity of Ducrosia anethifolia Boiss. and its linear furanocoumarins. Bio Med Res Int. 2014; 2014.

Shin E, Choi KM, Yoo HS, Lee CK, Hwang BY, Lee MK. Inhibitory effects of coumarins from the stem barks of Fraxinus rhynchophylla on adipocyte differentiation in 3T3-L1 cells. Biol Pharm Bull. 2010; 33: 1610-14.

Singh R, Singh B, Singh S, Kumar N, Kumar S, Arora S. Umbelliferone: An anti-oxidant isolated from Acacia nilotica (L.) Willd Ex Del. Food Chem. 2010; 120: 825-30.

Stevenson PC, Simmonds MSJ, Yule MA, Veitch NC, Kite GC, Irwin D, Legg $M$. Insect antifeedant furanocoumarins from Tetradium daniellii. Phytochemistry 2003; 63: 41-46.

Tabanca N, Tsikolia M, Ozek G, Ozek T, Ali A, Bernier UR, Duran A, Baser KHC, Khan IA. The identification of suberosin from Prangos pabularia essential oil and its mosquito activity against Aedes aegypti. Rec Nat Prod. 2016; 10: 311-25.

Tao Y, Zhang Y, Cheng Y, Wang Y. Rapid screening and identification of a-glucosidase inhibitors from mulberry leaves using enzyme-immobilized magnetic beads coupled with HPLC/MS and NMR. Biomed Chromatogr. 2013; 27: 148-55.

Tchamadeu MC, Dzeufiet PDD, Nouga CCK. Hypoglycaemic effects of Mammea africana (Guttiferae) in diabetic rats. J Ethnopharmacol. 2010; 127: 368-72.

Troia A, Raimondo FM, Castellano G, Spadaro V. Morphological, karyological and taxonomic remarks on Ferulago nodosa (L.) Boiss. (Apiaceae). Plant. Biosystems 2012; 146: 330 -37 .

Venugopala KN, Rashmi V, Odhav B. Review on natural coumarin lead compounds for their pharmacological activity. BioMed Res Int. 2013; 2013.

Wang C, Pei A, Chen J. A natural coumarin derivative esculetin offers neuroprotection on cerebral ischemia/reperfusion injury in mice. J Neurochem. 2012; 121: 1007-13.

Woldeyes S, Adane L, Tariku Y, Muleta D, Begashaw T. Evaluation of antibacterial activities of compounds isolated from Sida rhombifolia Linn. (Malvaceae). Nat Prod Chem Res. 2012; 1: $1-8$.

Zhang H, Su Y, Wang X, Mi J, Huo Y, Wang Z, Liu Y, Gao Y. Antidiabetic activity and chemical constituents of the aerial parts of Heracleum dissectum Ledeb. Food Chem. 2017; 214: $572-79$.
Author Info
Hilal Özbek (Principal contact)
e-mail: ozbek@atauni.edu.tr 